\title{
Direct Demonstration of Increased Expression of Thomsen-Friedenreich (TF) Antigen in Colonic Adenocarcinoma and Ulcerative Colitis Mucin and Its Concealment in Normal Mucin
}

Barry J. Campbell, lan A. Finnie, Elizabeth F. Hounsell, * and Jonathan M. Rhodes

Glycobiology Unit, Department of Medicine, University of Liverpool, Liverpool L69 3BX; and *Glycoprotein Structure/Function Group, Department of Biochemistry and Molecular Biology, University College London, London WC1E 6BT, United Kingdom

\begin{abstract}
Increased binding of the lectin peanut agglutinin is a common feature in epithelial malignancy and hyperplasia. This may have considerable functional importance in the intestine by allowing interaction between the epithelium and mitogenic lectins of dietary or microbial origin. Peanut agglutinin binds the disaccharide Thomsen-Friedenreich (TF,T or core 1) blood group antigen, Gal $\beta(1-3)$ GalNAc $\alpha-$, but is not totally specific for this site. Consequently, there has been controversy about the presence of this structure in colon cancer; studies with anti-TF monoclonal antibodies have failed to detect it. We have examined the presence of TF antigen in colonic mucus glycoprotein (mucin) using endo$\alpha$ - $N$-acetylgalactosaminidase $\left(O\right.$-Glycanase $\left.{ }^{\circledR}\right)$, which specifically catalyzes the hydrolysis of TF antigen from glycoconjugates. Samples of adenocarcinoma, inflammatory bowel disease (ulcerative colitis), and normal mucin were treated with $O$-glycanase, the liberated disaccharide was separated from the glycoprotein and analyzed using dual CarboPac PA-100 column high performance anion-exchange chromatography coupled with pulsed amperometric detection. $O$-Glycanase treatment released increased amounts of TF antigen from both colonic adenocarcinoma $(8.0 \pm 3.9 \mathrm{ng} / \mu \mathrm{g}$ protein, $n=11 ; P<0.0001$ ANOVA $)$ and ulcerative colitis mucin $(3.3 \pm 0.3 \mathrm{ng} / \mu \mathrm{g}$ protein, $n=5 ; P$ $=0.04)$ compared with mucin samples from histologically normal mucosa distant from carcinoma $(1.5 \pm 1.1 \mathrm{ng} / \mu \mathrm{g}$ protein, $n=9$ ). However, after mild acid treatment to remove sialic acids and fucose, releasable TF antigen was increased in all nine of these histologically normal mucin samples $(5.5 \pm 2.6 \mathrm{ng} / \mu \mathrm{g}$ protein, $P<0.0002)$. We conclude that TF antigen is an oncofetal antigen which is expressed in colon cancer, but is concealed by further glycosylation ( sialylation and/or fucosylation) in the normal colonic mucosa. (J. Clin. Invest. 1995. 95:571-576.) Key words: carbohydrate oncofetal antigen - colorectal cancer $\cdot$ mucus glycoprotein $\cdot$ ulcerative colitis $\cdot$ peanut agglutinin binding site
\end{abstract}

Address correspondence to Dr. Jonathan M. Rhodes, Department of Medicine, University of Liverpool, P.O. Box 147, Liverpool, L69 3BX, United Kingdom. Phone: 051-706-4073; FAX: 051-706-5802.

Received for publication 11 July 1994 and in revised form 12 September 1994.

J. Clin. Invest.

(C) The American Society for Clinical Investigation, Inc.

0021-9738/95/02/0571/06 \$2.00

Volume 95, February 1995, 571-576

\section{Introduction}

Increased binding of the lectin peanut agglutinin (PNA) ${ }^{1}$ is a common feature in epithelial malignancy and hyperplasia, occurring in colorectal tumors (1-3), both within the cells and in secreted material $(4,5)$, in adenomatous and metaplastic polyps $(2,3,6)$, and in the mucosa of patients with inflammatory bowel disease $(7,8)$. PNA binding is not detectable in normal colonic mucosa $(3,6,9)$, unless sensitivity is increased by avidin-biotin amplification $(2,6)$.

PNA has been shown previously to be mitogenic for normal human colonic epithelium (10), colorectal cancer cell lines ( 10 , 11 ), and for colonic polyp and inflammatory bowel disease mucosa (12). PNA binds to the disaccharide Thomsen-Friedenreich (TF) blood group antigen ( $\mathrm{Gal} \beta 1-3 \mathrm{GalNAc} \alpha-)$ which is a core carbohydrate structure of $\mathrm{O}$-linked oligosaccharides on glycoproteins (13). It has been suggested that this disaccharide behaves as an oncofetal antigen in many epithelial tissues becoming expressed in hyperplasia and malignancy; for example, TF is expressed in neonatal colon and meconium $(14,15)$ but in normal adult epithelium it is thought to be masked by further glycosylation and/or sialylation $(16,17)$. The hypothesis has been proposed (10) that increased expression of TF antigen by hyperplastic and malignant epithelia may be an important determinant of the altered proliferation, by allowing interaction with luminal $\mathrm{Gal} \beta 1-3 \mathrm{GalNAc}$-binding lectins of dietary and microbial origin.

However, there has been controversy about the presence of TF antigen in malignant tissues. PNA is not totally specific for TF $\alpha$ (Gal $\beta 1-3 \mathrm{GalNAc} \alpha-$, on glycoproteins ), possessing a high degree of affinity for both $\operatorname{TF} \beta(\mathrm{Gal} \beta 1-3 \mathrm{GalNAc} \beta-$, on glycolipids) and some affinity for type $1(\mathrm{Gal} \beta 1-3 \mathrm{GlcNAc} \beta 1-3)_{\mathrm{n}}$ chains $(18,19)$. This uncertainty has been increased by some studies which have failed to demonstrate $\mathrm{TF} \alpha$ in colonic malignant tissue using carbohydrate-specific monoclonal antibodies $(20,21)$. In addition, a rigorous analysis of the oligosaccharides in normal adult colonic mucin failed to detect $\mathrm{Gal} \beta 1-3 \mathrm{GalNAc}$ as a core structure (22). However, a study using D-galactose oxidase/Schiff's reagent (23) has suggested the presence of $\mathrm{Gal} \beta 1-3 \mathrm{GalNAc}$ in malignant tissues.

We have sought to clarify this confusion by specific quantification of TF $\alpha$ antigen released from histologically normal

1. Abbreviations used in this paper: AFGP, Antarctic fish antifreeze glycopeptides; Gal, D-galactose; GalNAc, $N$-acetyl-D-galactosamine; HPAEC, high-pH anion-exchange chromatography; $O$-glycanase, endo$\alpha$ - $N$-acetylgalactosaminidase; PAD, pulsed amperometric detection; PNA, peanut agglutinin; TF antigen, Thomsen-Friedenreich blood group antigen ( $\mathrm{Gal} \beta 1-3 \mathrm{GalNAc} \alpha-$ ). 
ulcerative colitis and carcinomatous colonic mucin, using highpH anion-exchange chromatography (HPAEC) coupled with pulsed amperometric detection (PAD) after specific enzymatic release with endo- $\alpha-N$-acetylgalactosaminidase ( $O$-glycanase), which hydrolyzes glycosidic bonds formed by $N$-acetylgalactosamine and the hydroxyl group of either serine or threonine only when in the sequence Gal $\beta 1-3 \mathrm{GalNAc}-\alpha-O-\mathrm{Ser} / \mathrm{Thr}(24,25)$.

\section{Methods}

\section{Materials}

Gal $\beta 1$-3GalNAc standard was purchased from Russell Fine Chemicals (Chester, United Kingdom); collagenase [EC 3.4.24.8], hyaluronidase [EC 3.2.1.35], and protease-free chondroitin ABC lyase [EC 4.2.2.4] from Boehringer Mannheim (Lewes, Sussex, United Kingdom); endo$\alpha$ - $N$-acetylgalactosaminidase $\left(O\right.$-Glycanase ${ }^{\circledR}$; from Streptococcus [ Diplococcus] pneumoniae ) [EC 3.2.1.97] and bovine testis $\beta$-galactosidase [EC 3.2.1.23] from Oxford Glycosystems Ltd. (Abingdon, Oxfordshire, United Kingdom). CAM17.1 monoclonal anti-mucin antibody was generously donated by Dr. Carol A. Makin (Imperial Cancer Research Fund, London, United Kingdom). The Antarctic fish (Trematomus borchgrevinki) antifreeze glycopeptides AFGP-I (antifreeze glycopeptides 1-5; BD-87-1-I) and AFGP-XV (antifreeze glycopeptides 7 and 8; CC-86-2-XV) were kind gifts from Professor Arthur L. DeVries (University of Illinois, Urbana, IL). Asialofetuin (type I), $\alpha$-L (-)-fucose, $N$-acetyl-D-galactosamine, and D-galactose were all purchased from Sigma Chemical Co. (Poole, Dorset, United Kingdom). D (+) melibiose (6-0- $\alpha$-D-galactopyranosyl-D-glucopyranoside) was purchased from BDH Chemicals Ltd. (Poole, Dorset, United Kingdom).

\section{Tissue specimens}

Surgical resection specimens were obtained from 11 patients with malignant colorectal adenocarcinoma, from 9 of which adjacent histologically normal colonic tissue (at least $10 \mathrm{~cm}$ away from carcinoma) was available. Five active ulcerative colitis colectomy specimens were also obtained. Tissue was stored at $-80^{\circ} \mathrm{C}$ before treatment.

\section{Purification of colonic mucus glycoproteins (mucin)}

Each surgical resection specimen was diced frozen and homogenized $\left(100 \mathrm{mg}\right.$ tissue/ml) using a Polytron ${ }^{\circledR}$ (Kinematica GmbH, KriensLuzern, Switzerland), in phosphate-buffered saline (PBS), $\mathrm{pH} 7.4$, containing a cocktail of protease inhibitors ( $2 \mu \mathrm{M}$ aprotinin, $10 \mu \mathrm{M}$ leupeptin, $5 \mathrm{mM}$ benzamidine hydrochloride, and $0.01 \% \mathrm{wt} / \mathrm{vol}$ thimerosal). Each homogenate was ultrasonicated and centrifuged using conditions described previously (26), and supernatants were desalted on PD10Sephadex GM25 $(5 \times 1.5 \mathrm{~cm})$ columns (Pharmacia AB, Uppsala, Sweden). Contaminating proteoglycans were removed by successive incubation with collagenase ( $1 \mathrm{mg} / \mathrm{ml}$ in PBS, $\mathrm{pH} 7.4)$, hyaluronidase $(1 \mathrm{mg}$ / $\mathrm{ml}$ in $20 \mathrm{mM}$ phosphate buffer, $\mathrm{pH} 5.8$ ), and protease-free chondroitin ABC lyase $(0.02 \mathrm{U} / \mathrm{ml}$ in $0.01 \mathrm{M}$ Tris- $\mathrm{HCl}, \mathrm{pH} 8.0)$, each for $6 \mathrm{~h}$, at $37^{\circ} \mathrm{C}$.

Mucin was purified from homogenates by Sepharose CL-2B minicolumns $(5 \times 1.5 \mathrm{~cm})$ eluted with PBS, pH 7.4, after which the void volume was subjected to high performance gel filtration using Superose 6 as described previously (26). Purified mucin was identified by ELISA using the CAM 17.1 anti-mucin monoclonal antibody (see reference 26) and assayed for protein using a bicinchoninic acid assay (kit BCA1; Sigma Chemical Co.), expressed relative to a standard of bovine serum albumin (BSA).

\section{Hydrolysis of Gal $\beta 1-3 G a l N A c$ using $O$-glycanase}

$O$-Glycanase was supplied in $10 \mathrm{mM}$ citrate/phosphate buffer, $\mathrm{pH} 6$, containing $25 \% \mathrm{vol} / \mathrm{vol}$ glycerol. The glycerol interfered with HPAEC analysis and was removed by two passages through Bio-Gel P30 polyacrylamide gel columns (Bio-spin ${ }^{\circledR}$; Bio-Rad Laboratories, Hercules, CA).

Lyophilized samples of purified colonic mucin (100 $\mu \mathrm{g}$ protein) were incubated with $0.6 \mathrm{mU}$ deglycerolated $O$-glycanase in $100 \mu 1100$ $\mathrm{mM}$ citrate/phosphate buffer, $\mathrm{pH} 6$, containing $100 \mu \mathrm{g} / \mathrm{ml} \mathrm{BSA}$ and $0.02 \% \mathrm{wt} / \mathrm{vol}$ sodium azide, for $18 \mathrm{~h}$ at $37^{\circ} \mathrm{C}$. Enzymatic release was confirmed using the antifreeze glycopeptides AFGP-I and AFGP-XV $(0-100 \mu \mathrm{g})$ and asialofetuin $(0-200 \mu \mathrm{g})$ as control TF-expressing substrates $(27,28)$. Appropriate control samples, incubated in the absence of $O$-glycanase and incubated with $O$-glycanase after pretreatment with bovine testis $\beta$-galactosidase, were studied.

$O$-Glycanase-liberated disaccharide was separated from intact glycoprotein and enzyme by sequential chromatography on Dowex 50X$12 \mathrm{H}^{+}$form resin $(3 \times 0.5 \mathrm{~cm})$, eluted with three column volumes of HPLC water, followed by PD10-Sephadex GM25. Fractions were monitored at an OD of $280 \mathrm{~nm}$ and using a phenol-sulfuric acid assay for neutral sugars (see later). Fractions containing neutral sugar (6.5$10.5 \mathrm{ml}$ ) were pooled, lyophilized, redissolved in $500 \mu \mathrm{l}$ HPLC water (Rathburn Chemicals, Walkerburn, United Kingdom), and filtered through $0.2-\mu \mathrm{m}$ (pore-size) Anotop IC ${ }^{\circledR}$ filters (Whatman, Maidstone, Kent, United Kingdom).

\section{Mild acid hydrolysis of mucin}

Lyophilized colonic mucin ( $100 \mu \mathrm{g}$ protein) was subjected to mild acid hydrolysis $\left(0.05 \mathrm{M}\right.$ sulfuric acid, $80^{\circ} \mathrm{C}$, for $\left.2 \mathrm{~h}\right)$ to release sialic acid and fucose $(15,29)$, followed by resolution of products using PD10Sephadex GM25. The hydrolyzed mucin was then subjected to $O$-glycanase treatment.

\section{Preparation of degalactosylated glycoproteins}

Lyophilized samples of colonic mucin ( $100 \mu \mathrm{g}$ protein), asialofetuin $(0-200 \mu \mathrm{g})$, and antifreeze glycopeptides AFGP-I and AFGP-XV (0$100 \mu \mathrm{g}$ ) were incubated with $10 \mathrm{mU}$ bovine testis $\beta$-galactosidase in $100 \mathrm{mM}$ citrate/phosphate buffer, $\mathrm{pH} 4$, for $6 \mathrm{~h}$ at $37^{\circ} \mathrm{C}$ (final volume, $20 \mu \mathrm{l}$ ). Treated glycoproteins, resolved using PD10-Sephadex GM25, were subjected to $O$-glycanase treatment.

\section{Phenol-sulfuric acid assay for neutral sugars}

A scaled down version of the method of Dubois et al. (30) was used. 10- $\mu \mathrm{l}$ samples were placed into ELISA microtiter plates (Dynatech Laboratories Inc., Chantilly, VA), agitated with $100 \mu \mathrm{l} 4 \% \mathrm{wt} / \mathrm{vol}$ phenol in distilled water, and left to stand for $5 \mathrm{~min}$. $150 \mu \mathrm{l}$ of concentrated sulfuric acid was added rapidly (with care) from a fast-delivery multichannel pipette and mixed immediately (five aspirations) to generate a high temperature. Plates were allowed to cool for $20 \mathrm{~min}$ and were read at $490 \mathrm{~nm}$. A water blank and standards of $0.5-20 \mu \mathrm{g}$ galactose (in triplicate) were included in each assay. The between assay coefficient of variation for standards was $7.7 \%(n=8)$.

\section{HPAEC}

Sample analysis was performed using a HPLC system coupled with PAD (Dionex UK, Camberley, Surrey, United Kingdom).

Oligosaccharide analysis. Gal $\beta 1-3 \mathrm{GalNAc}$ was separated using conditions described previously for neutral oligosaccharide alditols (31) . 100- $\mu$ l aliquots of $O$-glycanase reaction products, containing 320 ng of melibiose as internal standard, were injected onto the dual CarboPac PA-100 anion-exchange columns, calibrated with standard Gal $\beta 1$ 3GalNAc. The calibration curve for Gal $\beta 1-3$ GalNAc $(0.0625-1.0$ $\mu \mathrm{g}$ ), recovered from PD10-Sephadex GM25 (percent analytical recovery, $96.7 \pm 3.2$ [ mean $\pm \mathrm{SD}$ ]; $n=8$ ), was represented by the equation $y$ $=188.77 x-0.69(r=0.99)$ using peak height and internal standard ratio quantification analysis. The within assay coefficient of variation was $9.3 \%$, the between assay coefficient of variation was $10.1 \%(n=$ 8 ), and the lower limit of detection for Gal $\beta 1-3 \mathrm{GalNAc}$ ( $1 \mu \mathrm{A}$ output ) was $0.02 \mu \mathrm{g}$.

In addition, $O$-glycanase-liberated products were reduced to oligosaccharide alditols using alkaline-borohydride as described previously (31) and reanalyzed using HPAEC-PAD. Samples were compared with reduced standard Gal $\beta 1-3 \mathrm{GalNAc}$ and with the alditol R1-ol (Gal $\beta 1$ 3GalNAc-ol) derived from human meconium glycoprotein (15). 

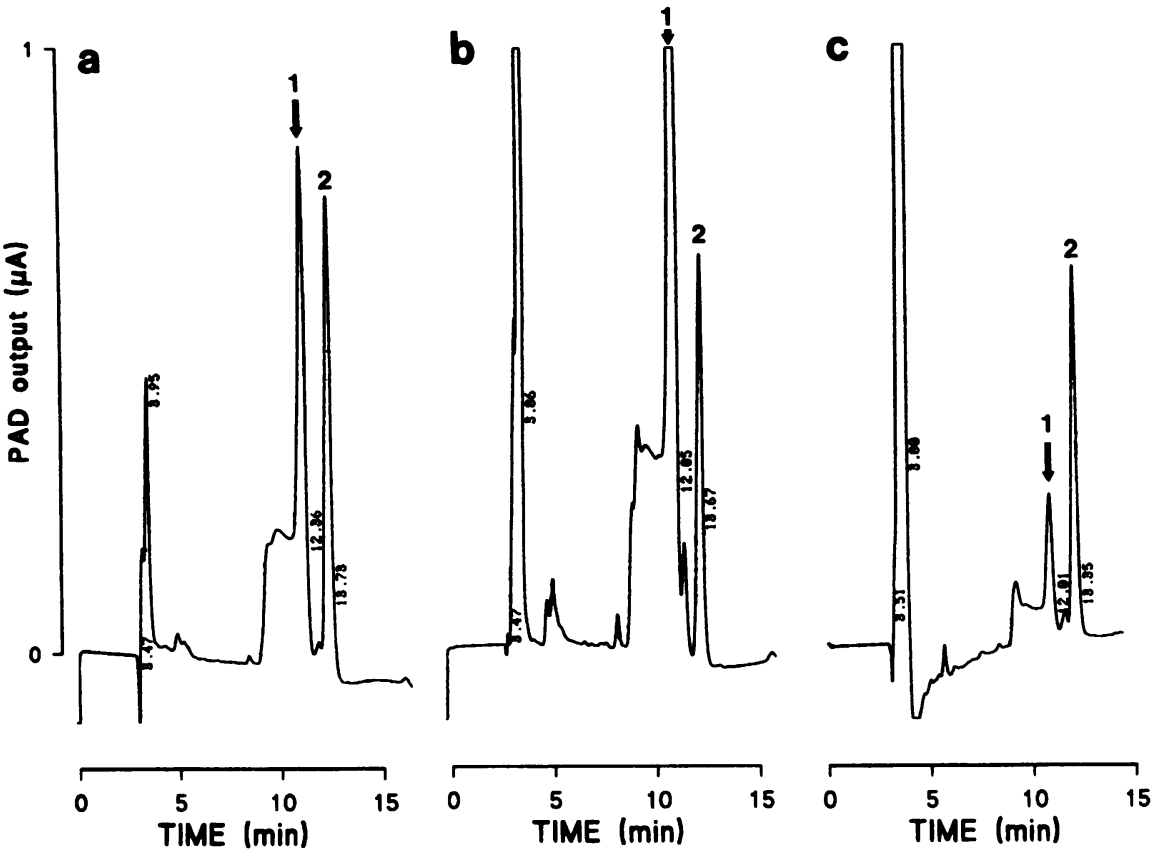

Figure 1. HPAEC separation of Gal $\beta 1$ 3GalNAc. All samples contained $320 \mathrm{ng}$ melibiose (2) as internal standard. (a) 0.5 $\mu \mathrm{g}$ standard $\mathrm{Gal} \beta 1 \rightarrow 3 \mathrm{GalNAc}(1)$ (arrows) and $\mathrm{Gal} \beta 1-3 \mathrm{GalNAc}$ liberated by $O$-glycanase from $(b)$ antifreeze glycopeptide AFGP-I and (c) colonic adenocarcinoma mucin. PAD output was $1 \mu \mathrm{A}$. The initial peak at $\sim 3.8 \mathrm{~min}$ is the solvent front.
Monosaccharide analysis. The monosaccharide composition of $O$ glycanase products was determined after digestion with $\beta$-galactosidase. $200-\mu 1$ aliquots of colonic mucin $O$-glycanase reaction mixtures were lyophilized and incubated with $10 \mathrm{mU}$ of $\beta$-galactosidase in $20 \mu \mathrm{l} 100$ $\mathrm{mM}$ citrate/phosphate buffer, $\mathrm{pH} 4$, for $6 \mathrm{~h}$ at $37^{\circ} \mathrm{C}$. $O$-Glycanasetreated antifreeze glycopeptides $(100 \mu \mathrm{l})$, asialofetuin $(200 \mu \mathrm{l})$, and $10 \mu \mathrm{g}$ standard $\mathrm{Gal} \beta 1-3 \mathrm{GalNAc}$ were identically treated. Aliquots (1$10 \mu \mathrm{l}$ ) of the $\beta$-galactosidase reaction mixtures were diluted to $100 \mu \mathrm{l}$ with HPLC grade water containing $100 \mathrm{ng} \mathrm{L}-\mathrm{fucose}$ as an internal standard, injected directly onto a single CarboPac PA-100 column, and eluted isocratically with $15 \mathrm{mM}$ sodium hydroxide for $20 \mathrm{~min}$, at 0.8 $\mathrm{ml} / \mathrm{min}$. $300 \mathrm{mM}$ sodium hydroxide solution (post-column reagent) was added to the column effluent at $0.6 \mathrm{ml} / \mathrm{min}$ to facilitate detection. PAD conditions were as described previously (31). Between each analysis the column was regenerated for $5 \mathrm{~min}$ with $20 \% 500 \mathrm{mM}$ sodium acetate $/ 15 \mathrm{mM}$ sodium hydroxide and then reequilibrated for $30 \mathrm{~min}$ with $15 \mathrm{mM}$ sodium hydroxide.

\section{Statistical analysis}

Sample groups were analyzed using Kruskall-Wallis nonparametric ANOVA (Arcus Pro-Stat ${ }^{\oplus}$; Medical Computing, Aughton, Lancashire, United Kingdom). Differences were considered significant when $P<$ 0.05 .

\section{Results}

Release of Galß1-3GalNAc (TF antigen) from mucin using $O$-glycanase. The treatment of colonic adenocarcinoma mucin with $O$-glycanase released a saccharide structure with a compatible retention time (using dual column HPAEC) to that of both standard Gal $\beta 1-3 \mathrm{GalNAc}$ and Gal $\beta 1-3 \mathrm{GalNAc}$ released by $O$-glycanase from the control TF antigen-expressing substrate AFGP-I (Fig. 1). Subsequent monosaccharide composition analysis of the $\boldsymbol{O}$-glycanase released saccharide from adenocarcinoma mucin and AFGP-I, after treatment with bovine testis $\beta$-galactosidase, produced two monosaccharide peaks consis- tent with galactose and $\mathrm{N}$-acetyl-galactosamine (Fig. 2). Likewise, alkaline-borohydride reduction of $O$-glycanase released products from adenocarcinoma mucin and the antifreeze glycopeptides resulted in a disaccharide alditol with a retention time comparable with R1-ol (Gal $\beta 1$-3GalNAc-ol, from human meconium glycoprotein) and to that of reduced standard Gal $\beta 1-$ 3GalNAc (data not presented).

$O$-Glycanase treatment released $\mathrm{Gal} \beta 1-3 \mathrm{GalNAc}$ from all three of the control TF antigen-expressing substrates AFGP-I $(393 \pm 32 \mathrm{ng} / \mu \mathrm{g}$ glycoprotein [GP]), AFGP-XV (227 $\pm 26 \mathrm{ng} /$ $\mu \mathrm{g} \mathrm{GP})$, and asialofetuin (42 $\pm 4 \mathrm{ng} / \mu \mathrm{g} \mathrm{GP})($ mean $\pm \mathrm{SD}, n=$ $6 ; 100-\mu \mathrm{g}$ sample). Pretreatment with $\beta$-galactosidase reduced the release of $\mathrm{Gal} \beta 1-3 \mathrm{GalNAc}$ by $O$-glycanase to $36 \pm 11$, $33 \pm 4$, and $25 \pm 4 \%$ of control levels, respectively.

Tissue expression of Gal $\beta 1-3 G a l N A c$. $O$-Glycanase treatment liberated $\mathrm{Gal} \beta 1-3 \mathrm{GalNAc}$ from 10 out of 11 colonic adenocarcinoma mucus glycoprotein samples $(8.0 \pm 3.9 \mathrm{ng} / \mu \mathrm{g}$ protein [mean $\pm \mathrm{SD}$ ], 95\% confidence intervals [CI] 5.2-0.8; $n=11)$ and from all 5 ulcerative colitis mucin samples $(3.3 \pm 0.3 \mathrm{ng} / \mu \mathrm{g}$ protein, $95 \%$ CI $2.2-4.4 ; n=5)$. Release of $\mathrm{Gal} \beta 1-3 \mathrm{GalNAc}$ from $O$-glycanase-treated histologically normal colonic mucin was, however, significantly lower $(1.5 \pm 1.1 \mathrm{ng} / \mu \mathrm{g}$ protein, $95 \% \mathrm{CI} 0.5-2.5 ; n=9)$ in comparison with adenocarcinoma $(P<0.0001$ ANOVA $)$ and colitic mucin $(P=0.04$ ANOVA $)$. Prior treatment of adenocarcinoma mucin with bovine testis $\beta$-galactosidase markedly reduced the release of $\mathrm{Gal} \beta 1-3 \mathrm{GalNAc}$ by $O$-glycanase $(1.7 \pm 0.8 \mathrm{ng} / \mu \mathrm{g}$ protein, $n=11)$ when compared with untreated samples $(8.0 \pm 3.9 \mathrm{ng} /$ $\mu \mathrm{g}$ protein; $P<0.0001$ ).

The total content of neutral $O$-glycans in both colonic adenocarcinoma $(0.68 \pm 0.2 \mu \mathrm{g} / \mu \mathrm{g}$ protein; $n=11, P<0.0001$ ANOVA) and ulcerative colitis mucins $(0.85 \pm 0.2 \mu \mathrm{g} / \mu \mathrm{g}$ protein; $n=5, P=0.002$ ) was significantly lower when compared with levels in histologically normal colonic mucin $(1.24 \pm 0.2$ $\mu \mathrm{g} / \mu \mathrm{g}$ protein; $n=9$ ). TF antigen, expressed as a proportion 


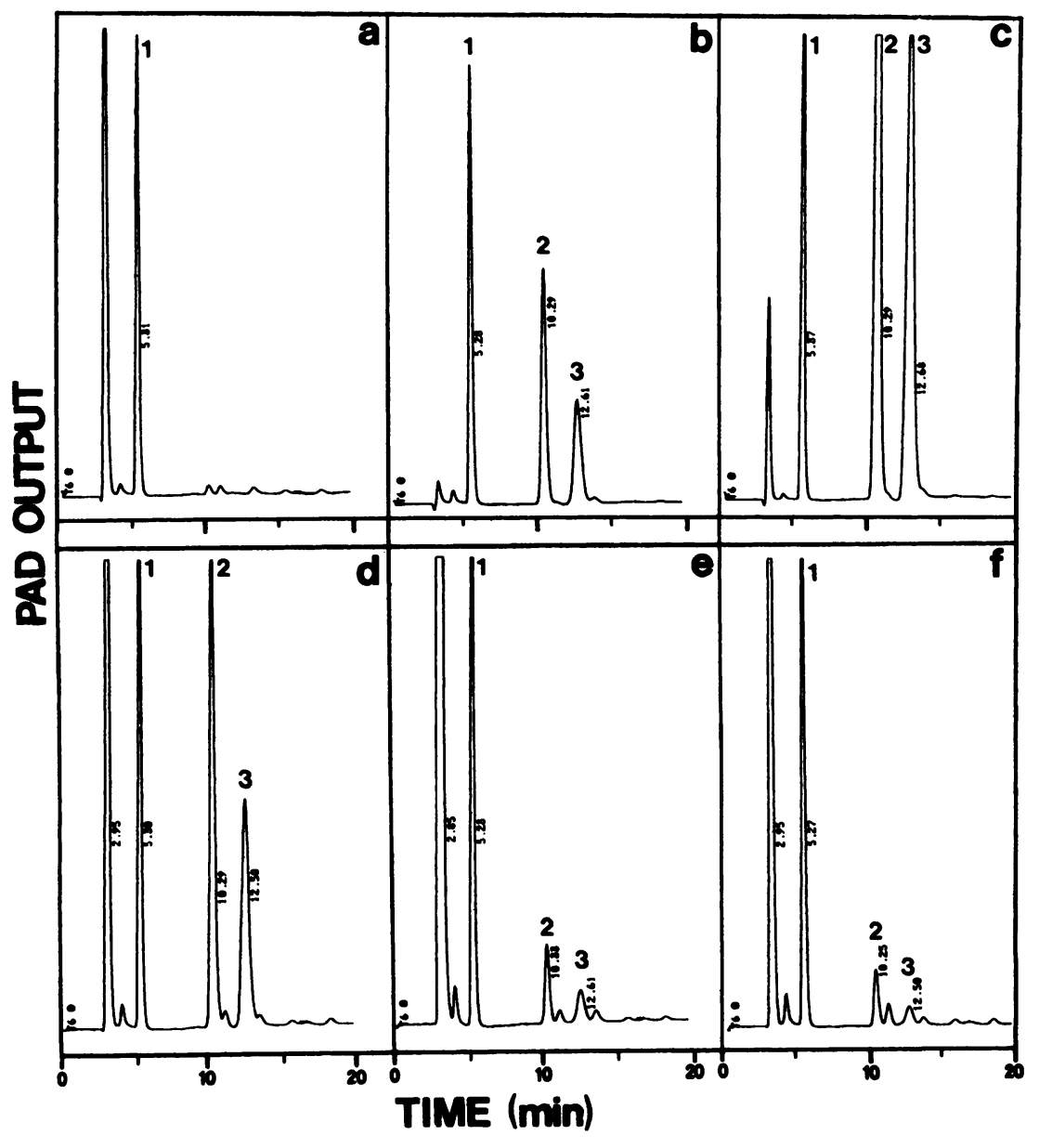

Figure 2. Monosaccharide composition analysis of $\beta$-galactosidase-treated $O$-glycanase reaction products using single CarboPac PA-100 column HPAEC. All samples contained $100 \mathrm{ng}$ L-fucose $(1)$ as internal standard (retention time, 5.27 min). (a) $\beta$-Galactosidase alone; (b) standard $N$-acetylgalactosamine (2) and galactose (3) (both $300 \mathrm{ng}$ ); (c) $\beta$-galactosidase-treated standard Gal $\beta 1$-3GalNAc; $(d-f) \beta$-galactosidasetreated $O$-glycanase-liberated disaccharide from antifreeze glycopeptide AFGP-I, colonic adenocarcinoma mucin, and mild acid-treated normal colonic mucin, respectively. PAD output was $1 \mu \mathrm{A}$.

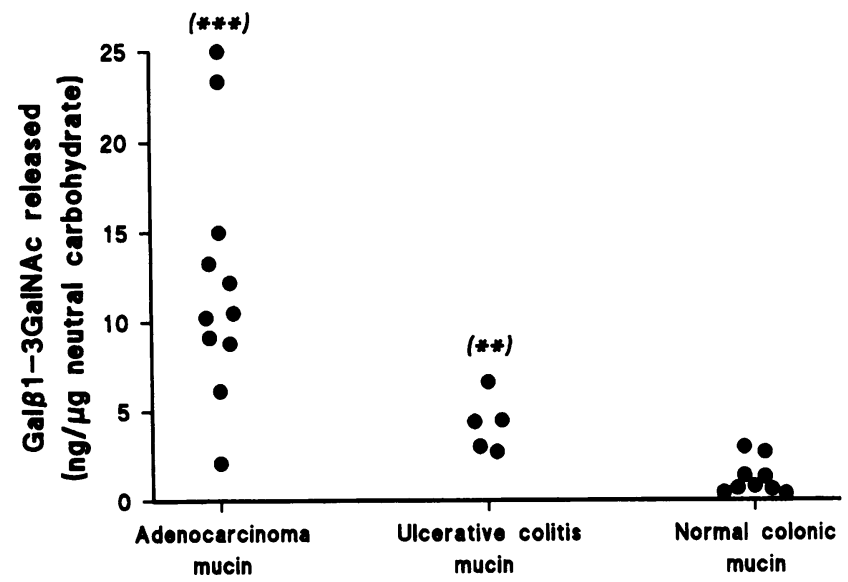

Figure 3. Gal $\beta 1-3 \mathrm{GalNAc}$, expressed as nanograms per microgram of mucin neutral carbohydrate, liberated by $O$-glycanase from mucin purified from colonic adenocarcinoma $(n=11)$, adjacent histologically normal $(n=9)$, and ulcerative colitis $(n=5)$ resection specimens. TF antigen was significantly higher in adenocarcinoma and colitic mucin samples when compared with normals. $* * * P<0.0001$ and $* * P$ $=0.0018$, respectively; ANOVA. of the neutral sugar content, was markedly increased in adenocarcinoma (12.3 $\pm 2.1 \mathrm{ng} \mathrm{Gal} \beta 1-3 \mathrm{GalNAc} / \mu \mathrm{g}$ neutral carbohydrate, 95\% CI 7.8-16.9; $n=11, P<0.0001$ ANOVA) and colitic mucin $(4.2 \pm 0.7 \mathrm{ng} / \mu \mathrm{g}$ neutral carbohydrate, $95 \% \mathrm{CI}$ 2.3-6.2;n $=5, P=0.0018)$ compared with the histologically normal mucin samples $(1.2 \pm 0.3 \mathrm{ng} / \mu \mathrm{g}$ neutral carbohydrate, 95\% CI $0.48-1.9 ; n=9$ ) (Fig. 3 ).

After mild acid treatment of histologically normal colonic mucin to remove sialic acids and fucose, levels of $\mathrm{Gal} \beta 1$ 3GalNAc released by $O$-glycanase treatment were substantially increased in all nine samples $(5.5 \pm 2.6 \mathrm{ng} / \mu \mathrm{g}$ protein, $95 \% \mathrm{CI}$ 3.5-7.6; $P=0.0002$ ANOVA) when compared with untreated normal mucin.

\section{Discussion}

This study provides the first conclusive demonstration of the presence of the Thomsen-Friedenreich (TF) carbohydrate antigen, D-galactose $\beta(1 \rightarrow 3$ ) D- $N$-acetylgalactosamine (in $\alpha$-anomeric configuration), in adult human intestinal mucin. The method uses the specificity of streptococcal endo- $\alpha$ - $N$-acetylgalactosaminidase $(24,25)$ which eliminates any possibility of detection of TF $\beta$ antigen released from glycolipids. Moreover, monosaccharide analysis has shown that the released disaccharide has the same composition as the disaccharide released by 
$O$-glycanase from TF $\alpha$ antigen-expressing antifreeze glycopeptide, which is glycosylated in the form of repeating diglycosyltripeptide units, Gal $\beta 1-3 \mathrm{GalNAc} \alpha-O$-(Thr-Ala-Ala-) (27). This study also confirms the increased expression of $\mathrm{Gal} \beta 1-3 \mathrm{GalNAc}$ in premalignant and malignant colonic mucosal disease and its relative lack of expression in histologically normal mucosa, which had previously been demonstrated indirectly by PNA histochemistry (1-9) and the D-galactose oxidase/Schiff's reactivity test (23).

In addition, we have shown an overall reduction in neutral $O$-glycans of $45 \%$ in human adenocarcinoma mucin when compared with histologically normal mucin, a fact consistent with data from a previous study of malignant colonic mucin (32). There was also a reduction in neutral carbohydrate content seen in ulcerative colitic mucin (32\%). Decreased mucin oligosaccharide side-chain length has been observed in active colitis and Crohn's disease (33) and oligosaccharide changes have also been demonstrated by alteration in the binding of anticarbohydrate antibodies and lectins $(9,34,35)$. It is interesting that so far no change in mucin structure has been found in inflammatory bowel disease that has not also been found in colon cancer and in hyperplastic or adenomatous colonic polyps. Although these changes in carbohydrate expression seem likely to be secondary to the disease process, they are likely to have very important functional consequences for mucosal protection (36), perhaps making the mucus more susceptible to degradation by bacterial mucus-degrading glycosidases which are secreted into the colonic lumen (37), and provide a good explanation for the marked thinning of the surface mucus layer seen in ulcerative colitis (38).

The increased availability of $\mathrm{Gal} \beta 1-3 \mathrm{GalNAc}$ for PNA binding in malignancy could be explained either by reduced sialylation $(16,17)$ or reduced fucosylation (39) of $\mathrm{Gal} \beta 1$ $3 \mathrm{GalNAc}$, or by a loss of the more common core 3 structure GlcNAc $\beta 1-3 G a l N A c$ (22), allowing preferential synthesis of core $1, \mathrm{Gal} \beta 1-3 \mathrm{GalNAc}$. Evidence from the present study, that mild acid hydrolysis reveals TF antigen in normal mucin, would suggest reduced sialylation or fucosylation as the mechanism, but a recent study has reported reduced $\beta 1-3 \mathrm{GlcNAc} \rightarrow \mathrm{Gal}-$ NAc transferase but unchanged $\beta 1-3 \mathrm{Gal} \rightarrow$ GalNAc transferase in colorectal carcinoma cells (40). It is quite likely that different mechanisms account for TF expression in different situations. Little is currently known about the mechanisms which regulate the relevant glycosyltransferases but ras oncogene transformation has been shown to result in decreased $\alpha 2-3 \rightarrow \mathrm{Gal} \beta 1-$ 3GalNAc sialyltransferase activity (41).

Mucins are the predominant glycoproteins secreted by colonic epithelium and unlike most membrane-bound glycoconjugates they can be isolated in sufficient quantity to permit biochemical analysis of their carbohydrate. However, histochemical studies suggest that changes in $O$-glycosylation of epithelial mucin are often paralleled by similar changes in the $O$-glycosylation of epithelial cell-surface glycoconjugates (3). We have recently proposed that increased TF antigen expression on hyperplastic and malignant epithelial cell-surface glycoconjugates may have functional significance by allowing interaction with $\mathrm{Gal} \beta 1-3 \mathrm{GalNAc}-$ binding lectins of dietary and microbial origin. These lectins can have marked effects on proliferation and mucosal metabolism. PNA, which resists digestion in the mammalian intestine, stimulates proliferation and mucus synthesis in vitro (10-12). Likewise, anti-TF monoclonal antibod- ies have been shown to produce similar marked effects on colorectal cancer cell line proliferation (42). Moreover, in a recent study we have shown that ingestion of peanuts for $1 \mathrm{wk}$ resulted in an increased rectal mitotic index of $40 \%$ in the one third of subjects (mainly irritable bowel syndrome) who had identifiable expression of PNA receptor by the histologically normal colonic mucosa (43). Other Gal-GalNAc-binding lectins, such as edible mushroom (Agaricus bisporus) and jack fruit (jacalin) lectins, cause noncytotoxic inhibition of proliferation of colorectal cell lines $(44,45)$. Therefore, it seems likely that the interaction of luminal dietary and microbial lectins with TF-expressing epithelial cells could be quantitatively as important as interaction with growth factors in determining the increased proliferation that occurs in hyperplasia and as a prelude to malignant change. Further studies are required to determine those glycosyltransferase changes which account for the increased expression of TF antigen.

\section{Acknowledgments}

The authors would like to thank Mr. M. J. Hershman (Department of Surgery, Royal Liverpool University Hospital) for his cooperation in obtaining the resection tissue specimens.

Ethical committee permission for this study was granted by the Royal Liverpool University Hospital Ethics committee (Liverpool, United Kingdom). B. J. Campbell was funded by the Medical Research Council and I. A. Finnie was funded by the Mersey Regional Health Authority.

\section{References}

1. Cooper, H. S. 1982. Peanut lectin binding sites in large bowel carcinoma. Lab. Invest. 47:383-390.

2. Cooper, H. S., and V. E. Reuter. 1983. Peanut lectin-binding sites in polyp of the colon and rectum. Adenomas, hyperplastic polyps and adenomas with insitu carcinoma. Lab. Invest. 49:655-661.

3. Rhodes, J. M., R. R. Black, and A. Savage. 1986. Glycoprotein abnormalities in colonic carcinomata, adenomata and hyperplastic polyps shown by lectinperoxidase histochemistry. J. Clin. Pathol. 39:1331-1334.

4. Boland, C. R., C. K. Montgomery, and Y. S. Kim. 1982. Alterations in human colonic mucin occurring with cellular differentiation and malignant transformation. Proc. Natl. Acad. Sci. USA. 79:2051-2055.

5. Itzkowitz, S. H., M. Yuan, C. K. Montgomery, T. Kjeldsen, H. K. Takahashi, W. L. Bigbee, and Y. S. Kim. 1989. Expression of Tn, sialosyl-Tn and T antigens in human colon cancer. Cancer Res. 49:197-204.

6. Boland, C. R. 1988. Lectin histochemistry in colorectal polyps. Prog. Clin. Biol. Res. 279:277-287.

7. Rhodes, J. M., R. R. Black, and A. Savage. 1988. Altered lectin binding by colonic epithelial glycoconjugates in ulcerative colitis and Crohn's disease. Dig. Dis. Sci. 33:1359-1363.

8. Boland, C. R., P. Lance, B. Levin, R. H. Riddell, and Y. S. Kim. 1984 Abnormal goblet cell glycoconjugates in rectal biopsies associated with an increased risk of neoplasia in patients with ulcerative colitis: a prospective study. Gut . 25:1364-1371.

9. Yuan, M., S. H. Itzkowitz, C. R. Boland, Y. D. Kim, J. T. Tomita, A. Palekar, J. L. Bennington, B. J. Trump, and Y. S. Kim. 1986. Comparison of Tantigen expression in normal, premalignant and malignant human colonic tissue using lectin and antibody immunohistochemistry. Cancer (Phila.). 46:48414847 .

10. Ryder, S. D., J. A. Smith, and J. M. Rhodes. 1992. Peanut lectin: a mitogen for normal human colonic epithelium and human HT29 colorectal cancer cells. J. Natl. Cancer Inst. 84:1410-1416.

11. Ryder, S. D., J. A. Smith, E. G. H. Rhodes, N. Parker, and J. M. Rhodes 1994. Proliferative responses of HT29 and Caco-2 human colorectal cancer cells to a panel of lectins. Gastroenterology. 106:85-93.

12. Ryder, S. D., N. Parker, D. Ecclestone, M. T. Haqqani, and J. M. Rhodes 1994. Peanut lectin stimulates proliferation in colonic explants from patients with inflammatory bowel disease and colon polyps. Gastroenterology. 106:117-124.

13. Hounsell, E. F., and T. Feizi. 1982. Gastrointestinal mucins: structure and 
antigenicities of their carbohydrate chains in health and disease. Med. Biol. 60:227-236.

14. Picard, J. K., and T. Feizi. 1983. Peanut lectin and anti-Ii antibodies reveal structural differences among human gastrointestinal glycoproteins. Mol. Immunol. 20:1215-1220.

15. Hounsell, E. F., A. M. Lawson, J. Feeney, H. C. Gooi, N. J. Pickering, M. S. Stoll, S. C. Lui, and T. Feizi. 1985. Structural analysis of the $O$-glycosidically linked core-region oligosaccharides of human meconium glycoprotein which express oncofetal antigens. Eur. J. Biochem. 148:367-377.

16. Springer, G. F. 1984. T and Tn: general carcinoma autoantigens. Science (Wash. DC). 224:1198-1206.

17. Lance, P., and R. Lev. 1991. Colonic oligosaccharide structures deduced from lectin-binding studies before and after desialylation. Hum. Pathol. 22:307 312 .

18. Lotan, R., E. Skutelsky, D. Danon, and N. Sharon. 1975. The purification, composition and specificity of the anti-T lectin from peanut (Arachis hypogaea) J. Biol. Chem. 250:8518-8523.

19. Chatterjee, B. P., H. Ahmed, G. Uhlenbruck, E. Janssen, C. Kolar, and F. R. Seiler. 1985. Jack fruit (Artocarpus integrifolia) and the Agaricus mushroom lectin fit also to the so-called peanut receptor. Behring Inst. Mitt. 78:148-158.

20. Longenecker, B. M., D. J. Willans, G. D. MacLean, S. Selvaraj, M. R. Suresh, and A. A. Noujaim. 1987. Monoclonal antibodies and synthetic tumorassociated glycoconjugates in the study of the expression of Thomsen-Friedenreich-like and Tn-like antigens on human cancers. J. Natl. Cancer Inst. 78:489492.

1. Orntoft, T. F., N. Harving, and N. C. Langkilde. 1990. O-linked mucintype glycoproteins in normal and malignant colon mucosa: lack of $\mathrm{T}$-antigen expression and accumulation of $\mathrm{Tn}$ and sialosly-Tn antigens in carcinomas. Int. J. Cancer. 45:666-672.

22. Podolsky, D. K. 1985. Oligosaccharide structures of human colonic mucin. J. Biol. Chem. 260:8262-8271.

23. Xu, H., K. Sakamoto, and A. M. Shamsuddin. 1992. Detection of the tumour marker D-galactose- $\beta$ - $(1 \rightarrow 3)-N$-acetyl-D-galactosamine in colonic cancer and precancer. Arch. Pathol. Lab. Med. 116:1234-1238.

24. Endo, Y., and A. Kobata. 1976. Partial purification and characterization of an endo- $\alpha-N$-acetylgalactosaminidase from the culture medium of Diplococcus pneumoniae. J. Biochem. 80:1-8.

25. Umemoto, J., K. L. Matta, J. J. Barlow, and V. P. Bhavanandan. 1978 Action of endo- $\alpha-N$-D-acetylgalactosaminidase on synthetic glycosides including chromogenic substrates. Anal. Biochem. 91:186-193.

26. Parker, N., I. A. Finnie, A. H. Raouf, S. D. Ryder, B. J. Campbell, H. H Tsai, D. Iddon, J. D. Milton, and J. M. Rhodes. 1993. High-performance gel filtration using monodisperse highly cross-linked agarose as a one-step system for mucin purification. Biomed. Chromatogr. 7:68-74.

27. Shier, W. T., Y. Lin, and A. L. DeVries. 1975. Structure of the carbohydrate of antifreeze glycoproteins from an Antarctic fish. FEBS (Fed. Eur. Biochem. Soc.) Lett. 54:135-138.

28. Spiro, R. G., and V. D. Bhoyroo. 1974. Structure of $O$-glycosidically linked carbohydrate units of fetuin. J. Biol. Chem. 249:5704-5717.

29. Ching, C. K., and J. M. Rhodes. 1990. Purification and characterization of a peanut-agglutinin-binding pancreatic cancer-related serum mucus glycoprotein. Int. J. Cancer. 45:1022-1027.

30. Dubois, M., K. A. Gilles, J. K. Hamilton, P. A. Rebers, and F. Smith 1956. Colorimetric method for determination of sugars and related substances. Anal. Chem. 28:350-356.

31. Campbell, B. J., M. J. Davies, J. M. Rhodes, and E. F. Hounsell. 1993. Separation of neutral oligosaccharide alditols from meconium using high-pH anion-exchange chromatography. J. Chromatogr. Biomed. Appl. 622:137-146.

32. Boland, C. R., and G. D. Deshmukh. 1990. The carbohydrate composition of mucin in colonic cancer. Gastroenterology. 98:1170-1177.

33. Clamp, J. R., G. Fraser, and A. E. Reid. 1981. Study of the carbohydrate content of mucus glycoproteins from normal and diseased colons. Clin. Sci. (Lond.). 61:229-234.

34. Podolsky, D. K., and D. A. Fournier. 1988. Alterations in mucosal content of colonic glycoconjugates in inflammatory bowel disease defined by monoclona antibodies. Gastroenterology. 95:371-378.

35. Jacobs, L. R., and P. W. Huber. 1985. Regional distribution and alterations of lectin binding to colorectal mucin in mucosal biopsies from control and subjects with inflammatory bowel disease. J. Clin. Invest. 75:112-118.

36. Rhodes, J. M. 1989. Colonic mucus and mucosal glycoproteins: the key to colitis and cancer? Gut. 30:1660-1666.

37. Hoskins, L. C., and E. T. Boulding. 1981. Mucin degradation in human colon ecosystems. Evidence for the existence and role of bacterial subpopulation producing glycosidases as extracellular enzymes. J. Clin. Invest. 67:163-172

38. Pullan, R. D., G. A. O. Thomas, M. Rhodes, R. G. Newcombe, G. T Williams, A. Allen, and J. Rhodes. 1994. Thickness of adherent mucus gel on colonic mucosa in humans and its relevance to colitis. Gut. 35:353-359.

39. Okada, Y., M.-A. Sotozono, N. Sakai, T. Yonei, S. Nakanishi, and T. Tsuji. 1994. Fucosylated Thomsen-Friedenreich antigen in $\alpha$-anomeric configuration in human gastric surface epithelia: an allogenic carbohydrate antigen possibly controlled by the Se gene. J. Histochem. Cytochem. 42:371-376.

40. King, M. J., A. Chan, R. Roe, B. F. Warren, A. Dell, H. R. Morris, D. C. C. Bartolo, P. Durdey, and A. P. Corfield. 1994. Two different glycosyltransferase defects that result in GalNAc $\alpha$-O-peptide (Tn) expression. Glycobiology . 4:267279.

41. Delannoy, P., H. Pelczar, V. Vandamme, and A. Verbert. 1993. Sialyltransferase activity in FR3T3 cells transformed with ras oncogene: decreased CMP NeuAc:Gal $\beta 1$-3GalNAc alpha-2,3-sialyltransferase. Glycoconjugate Journal. 10 91-98.

42. Yu, L. G., B. Jansson, J. D. Milton, and J. M. Rhodes. 1994. Stimulation of proliferation in HT29 colon cancer cells by monoclonal antibodies to TF blood group antigen. Gastroenterology. 106:454a. (Abstr.)

43. Ryder, S. D., M. R. Jacyna, A. J. Levi, and J. M. Rhodes. 1993. Peanut eating increases colonic epithelial proliferation. Gut. 34:S68a. (Abstr.)

44. Yu, L. G., D. G. Fernig, J. A. Smith, J. D. Milton, and J. M. Rhodes 1993. Reversible inhibition of proliferation of epithelial cell lines by Agaricus bisporus (edible mushroom) lectin. Cancer Res. 53:4627-4632.

45. Zhou, Z.-Q., L. Yu, J. D. Milton, and J. M. Rhodes. 1993. Jacalin causes non-cytotoxic inhibition of proliferation in HT29 colon cancer cells. Clin. Sci. 85:11P. (Abstr.) 